\title{
原
}

( J.Soc.Cosmet.Chem.Jpn 著

\section{植物系ワックスを由来とする「しなやかさ」に優れる 新規皮膜形成剂の開発とマスカラ製剤への応用*}

\author{
渡辺 恵 悟, 柿 沢 英 美, 奥 山 雅樹 \\ 株式会社コーセー 研究所**
}

\begin{abstract}
マスカラにおいて, まつ毛のカール固定およびカ一ル保持は必要不可欠な機能である。従来はカー ル固定および保持機能の演出のために, 硬さに優れるワックスと柔軟性に優れるレジンを併用し， ワックスに可塑性を付与するという技術が用いられてきた。しかしながら，この技術により得られた 皮膜はワックスの脆さを完全には解消することができず，またレジン由来のべたつきを有するもので あった。よって, 両者の長所である硬さと柔軟性を併せ持ちながらも, 短所である脆さとべたつきを 解消した皮膜形成剤の開発が望まれていた。今回, 植物系ワックスの中で最も硬い領域にある「カル ナウバワックス」の成分組成に着目し，固液抽出法を用いてカルナウバワックス中のレジン成分の濃 度を高めることで，新規皮膜形成剤「カルナウバロウエキス」の開発に成功した。カルナウバロウエ キスは, カルナウバワックスの特長である硬さは維持しながらも, 課題である脆さが解消されている ことが物性測定により明らかになった。実際に力ルナウバロウエキスを配合した油性マスカラは, 従 来の製剤と比較してまつ毛のカール形状の固定および保持効果が向上し，マスカラにおいて優れた皮 膜形成剤になる可能性が示唆された。
\end{abstract}

\section{1. 緒言}

近年，目元に重点を置いたメイクの流行により，印象 的な目元づくりのできるアイテムとしてマスカラが注目 されている。その中でも，単にまつ毛のカール状態を長 時間固定・保持するだけでなく，毛髪本来の「しなやか」 なテクスチャーを維持した自然な仕上がりを演出できる マスカラが求められている。

一般的にマスカラにおいては，ワックスや樹脂（レジ

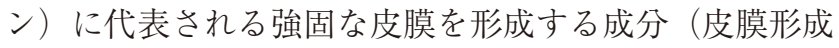
剂）がまつ毛形状の固定・保持に大きく寄与しており, これまでに天然ワックスを改変したものや合成ポリマー

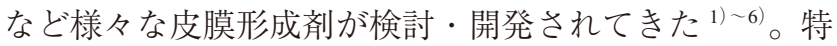
にワックスは硬くてべたつきのない皮膜を形成すること で優れた形状固定機能を発揮するため，マスカラにおい て必須の成分となっている。しかしながら，その反面皮 膜に柔軟性がなく脆いため，ワックスを配合した製剤は

*2015.7.13 受付, 2015.10.21 採用

**テ114-0005 東京都北区栄町 48-18：48-18, Sakae-cho, Kita-ku, Tokyo 114-0005, Japan
経時で化粧膜のひび割れや脱落が起こりやすく，形状保 持の機能には劣るという課題があった。この課題を解決 するため，従来はワックスにレジンのような可塑剤を添 加することで柔軟性を付与し，脆さを低減するという技 術が用いられてきたが7)，得られたマスカラ塗膜はレジ ン由来のべたつきを有していたために，まつ毛同士が くっつき合う「束づき」が起こり，自然な仕上がりを実 現することが困難であった。よって，より高い形状固 定・保持機能を発揮し，かつ束づきのない自然な仕上が りを演出するマスカラを実現するためには，ワックスの 長所である硬さとべたつきのなさを維持しつつも，課題 である脆さを克服した，「しなやかさ」に優れる皮膜形 成剤の開発が必要であった。

硬さと柔軟性を両立した「しなやか」な皮膜形成剂の 開発のためには，硬さに寄与する結晶成分と柔軟性に寄 与する非晶成分を共存させることが求められる。しかし 一般的に，化学的性質の全く異なる結晶成分と非晶成分 をブレンドし，安定な状態で相溶させることは非常に困 難であるため，例えば合成ポリマーを複合化する際に は，両者の「つなぎ」となる相溶化剛の添加が必要であっ た ${ }^{8)}$ 。 
これらの状況を踏まえ, 今回われわれは, 結晶成分と 非晶成分が天然の状態で相溶化され安定に共存している 「植物系ワックス」に着目した。そして植物系ワックス の中で最も硬い物性領域にあり，かつ安全性にも優れる ために形状固定機能付与の目的で化粧品において長年に 渡り使用されてきた「カルナウバワックス」を出発原料 として選択し，その成分組成を改変することで目的とす る皮膜形成剂の開発を試みた。

本稿ではその組成検討の内容と, 開発した新規皮膜形 成剂の塗膜物性評価, 毛髪に対する形状固定・保持機能 の検証，そしてマスカラ製剤における機能性評価の結果 について報告する。

\section{2. 実験}

\section{1. カルナウバワックスの成分改変検討}

\subsection{1. 成分改変スキームの検討}

カルナウバワックスおよびその他の代表的な天然系 ワックスの成分組成および融点を Table-1 に示す ${ }^{9)}$ 。 ルナウバワックスは, 主にろうエステルおよび脂肪族ア ルコールから構成される約 $90 \%$ のワックス成分と, 遊
離カルボン酸およびその低分子エステルから構成される 約 5\%のレジン成分，そして約 5\%のその他成分（遊離 脂肪酸，炭化水素）により構成されている。この成分組 成における特徴として，他のワックスと比べてワックス 成分の割合が大きく，さらにろうエステルの分子量も大 きいこと，その反面レジン成分の割合が小さいことが挙 げられる。実際に GC-MS（GC-17A，島津製作所）を用 いたカルナウバワックスの質量分析においては，ろうエ ステルに起因するピークはスペクトルの最も高分子量側 に，脂肪族アルコールに起因するピークは中分子量領域 に強い強度で現れ，一方でレジン成分に起因するピーク は低分子量領域にごく小さく観察された（Fig.-1および Table-2)。天然系ワックスの中で融点が高く硬さに非常 に優れる反面，柔軟性が低く脆いというカルナウバワッ クスの物性は，この成分組成に起因していると考えられ る。

以上の成分分析によりわれわれは，カルナウバワック スを原料として，硬いワックス成分の濃度を低減し，柔 軟なレジン成分の濃度を高めることで，硬さというカル ナウバワックスの長所を維持したまま，課題である脆さ を解消することができるのではないかと仮説を立てた。

Table-1 Compositions and melting points of carnauba wax and other natural waxes.

\begin{tabular}{lcccccccc}
\hline Components & \multicolumn{2}{c}{ Carnauba wax } & \multicolumn{2}{c}{ Rice wax } & \multicolumn{2}{c}{ Candelilla wax } & \multicolumn{2}{c}{ Bees wax } \\
\hline Wax esters & $\mathrm{C} 48-\mathrm{C} 64$ & $80-85 \%$ & $\mathrm{C} 40-\mathrm{C} 64$ & $93-97 \%$ & $\mathrm{C} 42-\mathrm{C} 56$ & $24-30 \%$ & $\mathrm{C} 40-\mathrm{C} 52$ & $67-72 \%$ \\
Higher fatty alcohols & $\mathrm{C} 16-\mathrm{C} 32$ & $10-12 \%$ & - & - & $\mathrm{C} 26-\mathrm{C} 34$ & $10-15 \%$ & $\mathrm{C} 24-\mathrm{C} 32$ & $1-2 \%$ \\
Free fatty acids & $\mathrm{C} 16-\mathrm{C} 32$ & $3-4 \%$ & $\mathrm{C} 16-\mathrm{C} 18$ & $4-7 \%$ & $\mathrm{C} 20-\mathrm{C} 35$ & $10-20 \%$ & $\mathrm{C} 16-\mathrm{C} 32$ & $13-16 \%$ \\
Hydrocarbons & $\mathrm{C} 30-\mathrm{C} 33$ & $1-3 \%$ & - & - & $\mathrm{C} 20-\mathrm{C} 33$ & $40-50 \%$ & $\mathrm{C} 21-\mathrm{C} 35$ & $10-14 \%$ \\
Resin component & Carboxylic acids, & $3-4 \%$ & - & - & Triterpens, & $15-18 \%$ & Glycerides & $3-4 \%$ \\
Melting point & Diterpens & $80-86^{\circ} \mathrm{C}$ & & $70-77^{\circ} \mathrm{C}$ & & Tetracyclenes \\
\hline
\end{tabular}

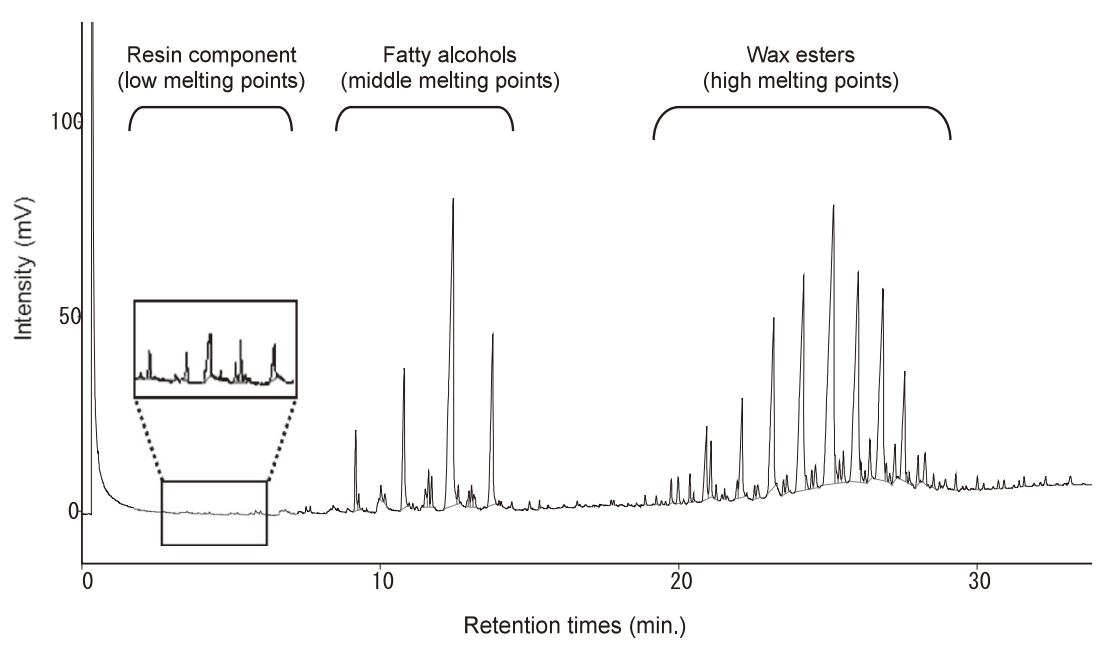

Fig.-1 Gas chromatograms of carnauba wax. 
Table-2 Conditions for gas chromatography measurement.

\begin{tabular}{|c|c|}
\hline Column & $\begin{array}{l}100 \% \text { dimethylpolysiloxane capillary column, length }: 15 \mathrm{~m} \text {, internal diameter }: 0.25 \mathrm{~mm} \text {, } \\
\text { thickness of film }: 0.15 \mu \mathrm{m}\end{array}$ \\
\hline Detector & FID (Flame Ionization Detector) \\
\hline Amount of sample & $2 \mu \mathrm{L}$ \\
\hline Temperature of nozzle & $380^{\circ} \mathrm{C}$ \\
\hline Temperature of detector & $380^{\circ} \mathrm{C}$ \\
\hline Temperature of column & $150^{\circ} \mathrm{C}$ for $1 \mathrm{~min}$, rise to $380^{\circ} \mathrm{C}$ at speed of $7.5^{\circ} \mathrm{C} / \mathrm{min}$, and at $380^{\circ} \mathrm{C}$ for $13 \mathrm{~min}$ \\
\hline Carrier gas & $\mathrm{He}(2.01 \mu \mathrm{L} / \mathrm{min})$ \\
\hline
\end{tabular}

ワックス成分とレジン成分とでは分子量および極性が 異なるため, 有機溶媒に対する溶解度にも差があると考 えられる。そこでこの溶解度の差を利用し, 有機溶媒を 用いた固液抽出法によりカルナウバワックス中からワッ クス成分を抽出除去することでレジン成分の濃縮を試み た。

\subsection{2. レジン抽出サンプルの作製}

試料であるカルナウバワックスを溶媒であるエタノー ルーヘキサン混合溶媒に加え, これを加熱した状態で一 定時間浸漬した。その後, ろ過により未溶解物を取り除 き, 万液を採取した。得られたろ液から溶媒留去して乾 固することにより抽出サンプルを得た。

目的とする硬さと適度な柔軟性を併せ持つ皮膜形成剂 を得るためには, レジン成分の濃度を最適化する必要が ある。そこで最適なレジン濃度を得られる抽出工程を見 出すため, 工程に抢いて, (1)エタノールーヘキサンの比 率, (2)抽出温度, (3)抽出時間, (4)試料濃度, という 4 つ の抽出条件を検討した。

\section{2. 最適組成の検討}

条件検討により得られた 5 つのサンプル $\mathrm{A} \sim \mathrm{E}$ の中か ら, 求める物性を有するものを見出すため, 結晶構造の 観察, 組成分析㧍よび物性解析によりサンプルのスク リーニングを行った。

\subsection{1. 結晶構造解析}

各サンプルの結晶状態を把握するため, 光学顕微鏡 (BX51-34-FLD-SP，オリンパス社製）を用いて結晶構造 の観察を行った。観察条件としては, スライドガラス上 に塗布したサンプルを $110^{\circ} \mathrm{C}$ に加熱して完全に融解させ たのち, $30^{\circ} \mathrm{C}$ に冷却固化したものを倍率 100 倍で観察し た。

\subsection{2. 熱分析による成分組成解析}

各サンプルについて成分組成を把握するため, 示差走 査熱量計（DSC6200，セイコーインスッルメンッ社製） による熱分析を行い, 熱変化に伴う各サンプル中の成分 の挙動を観察した。

\subsection{3. 物 性 解 析}

結晶構造解析掞よび成分組成解析の結果によりサンプ ルの一次スクリーニングを行い, サンプルを 5 つから 3 つへ絞り込んだ。さらにその中から最適な物性を有する ものを見出すために，硬度掞よび柔軟性の評価を行っ た。

硬度についてはレオメーター（FUDOH RTC-2002，レ オテック社製）を用い, 直径 $3 \mathrm{~mm}$ の針状アダプターを $2 \mathrm{~cm} / \min$ のスピードで各サンプル表面に押し当て，ア ダプターが深さ $1 \mathrm{~mm}$ に達した時点での最大荷重值を計 測し, 各サンプルにつき 3 回計測した值の平均值により 評価した。柔軟性については, 加熱溶融した各サンプル をガラス板上に流し，固化する前にドクターブレードを 用いて $400 \mu \mathrm{m}$ の塗膜を作製し，その塗膜にクロスカッ 卜試験機 (YASUDA 551-AUTO-1, 安田精機製作所社製) で切り込みを入れ, 膜の状態 (均一性, 連続性)を観察 することで評価した。これらの評価結果により最適物性 を有するサンプルを決定した。

\section{3. 機能性評価}

\subsection{1. 毛髪に対する形状固定・保持機能評価}

決定した最適サンプルが実際に毛髪に対して形状固定 および保持機能を発揮するかどうか検証するため, サン プルを毛髪にコーティングし，それを曲げる際に発生す る応力を測定した。まず，加熱溶融した決定サンプルお よび比較品であるカルナウバワックスを $1 \mathrm{~cm}$ の長さに 切断した同一毛髮に塗布したのち, 冷却して固化した。 次に, テクスチャーアナライザー (TA.XT Plus, Stable Micro Systems 社製）を用い，Fig.-2のように両端を固 定した各々の毛髪に $0.1 \mathrm{~mm} / \mathrm{sec}$ の速さで圧縮動作を加 えて曲げていき, 曲げに伴い発生する応力の挙動を測定 した。さらに，毛髪を元の状態に戻したあとに同じ曲げ 動作を続けて 2 回繰り返すことで, 連続的な衝撃を加え た際の応力の変化を比較した。

\subsection{2. マスカラ製剤における機能評価}

決定サンプルまたは比較品であるカルナウバワックス を配合した油性マスカラについて機能評価を行った。専 
門パネル 1 名が通常の使用と同じようにまつ毛にマスカ ラを塗布し，塗布直後のまつ毛のカール固定効果および セパレート効果, さらに塗布 8 時間後のカール保持効果 を評価した。なお，カール固定効果および保持効果はま つ毛のカール角度を計測することで評価した。この際の カール角度は, 目を真横から撮影した写真において, ま つ毛の生え際から水平に引いた直線と, まつ毛の生え際 からまつ毛の先端を結んだ直線との角度と定義した。

\section{3. 結果および考察}

\section{1. 抽出サンプルにおける成分組成の把握}

\subsection{1. 抽出サンプルの特徵}

サンプル $\mathrm{A} \sim \mathrm{E}$ に対応する抽出条件を Table-3に示 す。抽出条件の検討にあたってはまず，抽出溶媒の選定 を行った。抽出ターゲットであるレジン成分は極性が高 いと考えられるため, 極性溶媒のエタノールをメインの 溶媒とし，へキサンを混合することで極性の調整を行っ た。次に, 抽出工程に関しては, 溶媒中に原料である力 ルナウバワックスを投入し, 穏やかに加熱しながら一定 時間擋拌を続けたところ, ワックスが膨潤し, 溶媒の浸 透が確認できた。検討の結果, この膨潤の程度は, 擋拌 温度がより高く，また試料濃度がより小さい場合におい て著しいことがわかった。以上より，溶媒の極性（エ夕

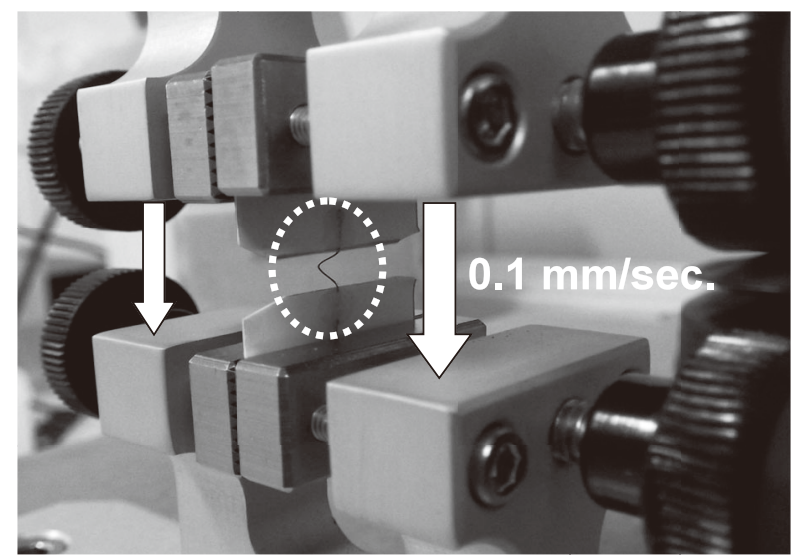

Fig. -2 Hair bending test with a Texture Analyzer. The dotted circle indicates the hair during a bending test.
ノールとヘキサンの割合), 抽出温度, 試料濃度, そし て抽出時間という 4 つの条件により抽出レジン量をコン トロールできると考え，これらの条件を変えることで抽 出工程の検討を行った。

工程検討の結果，各工程から得られたサンプルの外観 および性状を Fig.-3に示す。抽出溶媒においてエ夕 ノールの割合がより大きい工程から得られたサンプル A および B の感触は柔らかく，かつべたつきが強く，ま た外観はガム状であった。これら結果より, サンプル A およびBにおいてはレジン成分の濃度が大きいと推察 された。これは, 抽出工程において溶媒のエタノールの 割合が大きいために，より極性の高いレジン成分が優先 的に抽出されたことが要因であると考えられる。一方， 溶媒においてエタノールの割合が小さく, また抽出温度 の高い工程から得られたサンプル $\mathrm{C} \sim \mathrm{E}$ は，べたつきが 弱く，外観もワックス状であった。これらの結果より， サンプル C $\mathrm{E}$ においてはワックス成分の濃度が大きい と推察された。これは，工程に扔いて擋汼温度が高いた めに，原料であるカルナウバワックスがより膨潤し， ワックス成分が優先的に溶媒に溶け出したことが要因で あると考えられる。

\subsection{2. 結晶構造解析}

前項で各サンプルの外観掞よび性状の評価によりレジ ン濃度を推定したが，その推定の妥当性を確かめるため に光学顕微鏡による結晶構造観察を行った。得られた結 晶画像を Fig.-4に示す。まず，原料であるカルナウバ ワックスに抏いては，結晶性の高いエステル成分が支配 的であるため，顕微鏡画像においてはエステルに由来す るサイズの大きい結晶が観察された。ところがサンプル $\mathrm{A}$ 抢よび B の結晶構造においては，このエステル由来 の結晶が消失し, 非晶質構造が一面に観察されているこ とから，ワックス濃度がかなり小さくなっていると考え

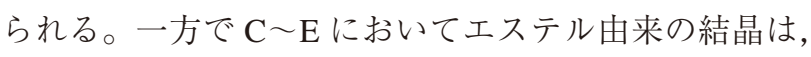
カルナウバワックスと比較すると数は減少しているもの の，はっきりと観察されたことから，レジン濃度が大き くなりつつも，まだワックス成分が支配的であると考え られる。以上の結晶構造観察結果より, サンプル A お よび B においてはレジン成分が支配的であり，一方で

Table-3 Extraction conditions for each sample.

\begin{tabular}{lccccc}
\hline \multicolumn{1}{c}{ Sample No. } & A & B & C & D & E \\
\hline Extractant (Ethanol $:$ Hexane $)$ & $9.1: 0.9$ & $9.1: 0.9$ & $9: 1$ & $9: 1$ & $9: 1$ \\
Extracting temperature $\left({ }^{\circ} \mathrm{C}\right)$ & 30 & 30 & 40 & 40 & 40 \\
Sample concentration $(\mathrm{g} / \mathrm{mL})$ & 0.33 & 0.31 & 0.50 & 0.31 & 0.30 \\
Extracting time (hour) & 4 & 3 & 3 & 3 & 3 \\
\hline
\end{tabular}




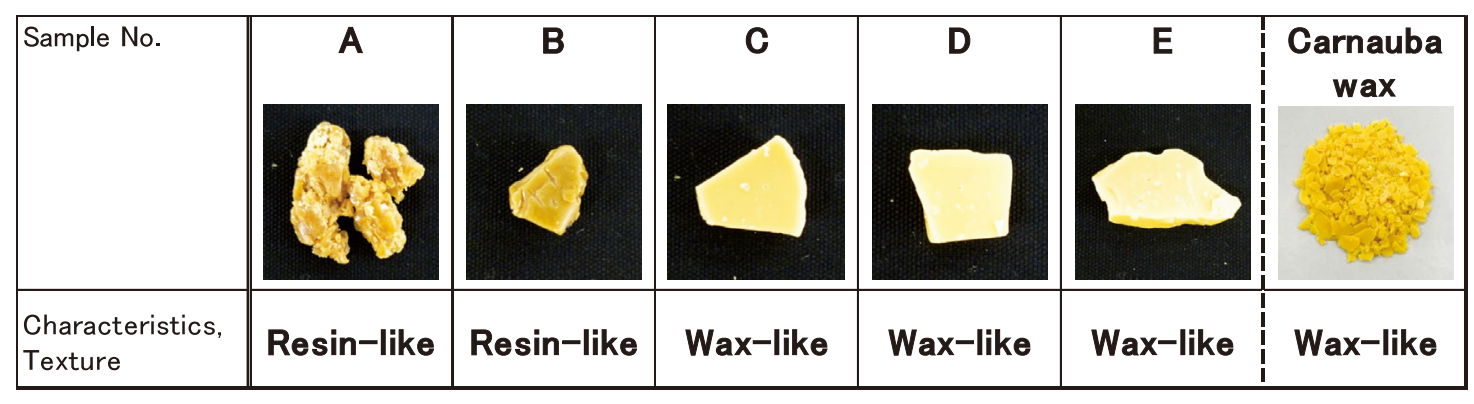

Fig.-3 External appearances of extraction samples.
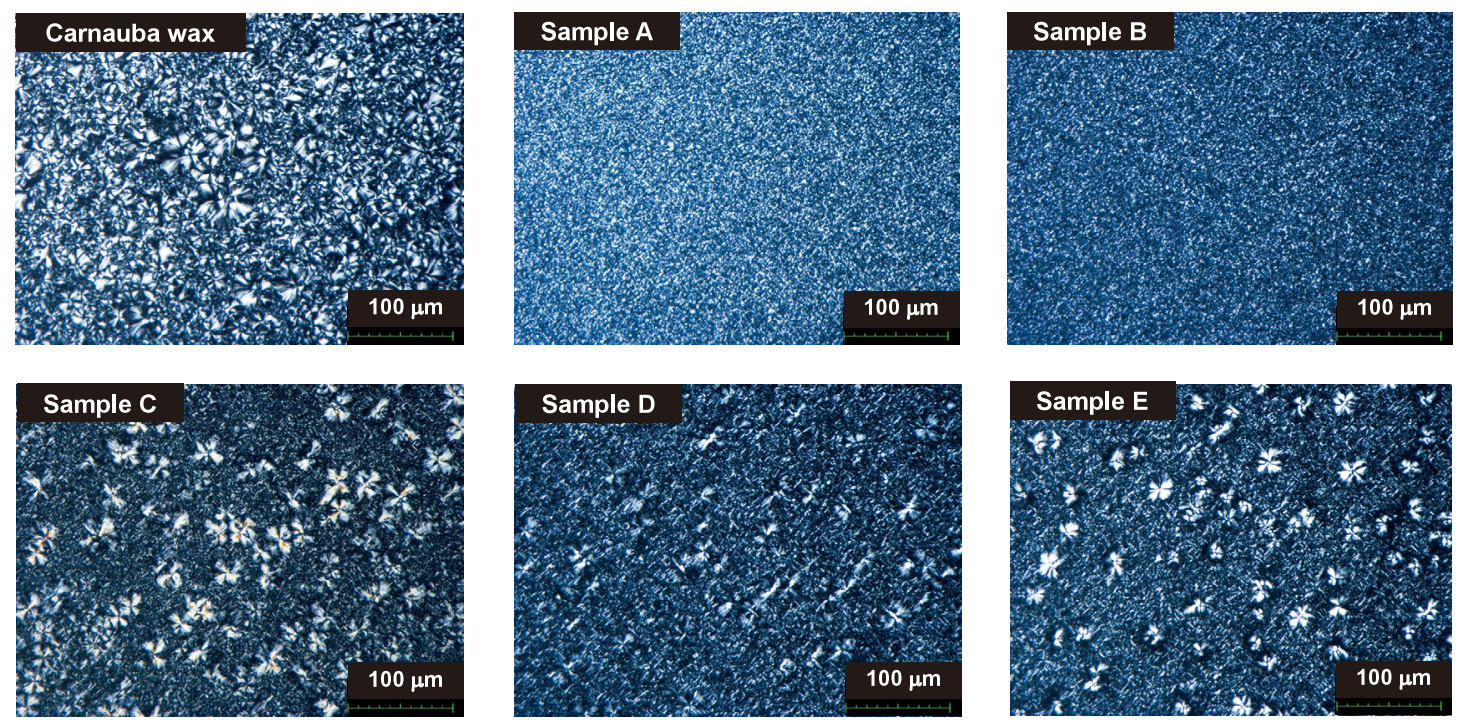

Fig. -4 Optical microscopic images (a magnification of 100 times) of extraction samples.

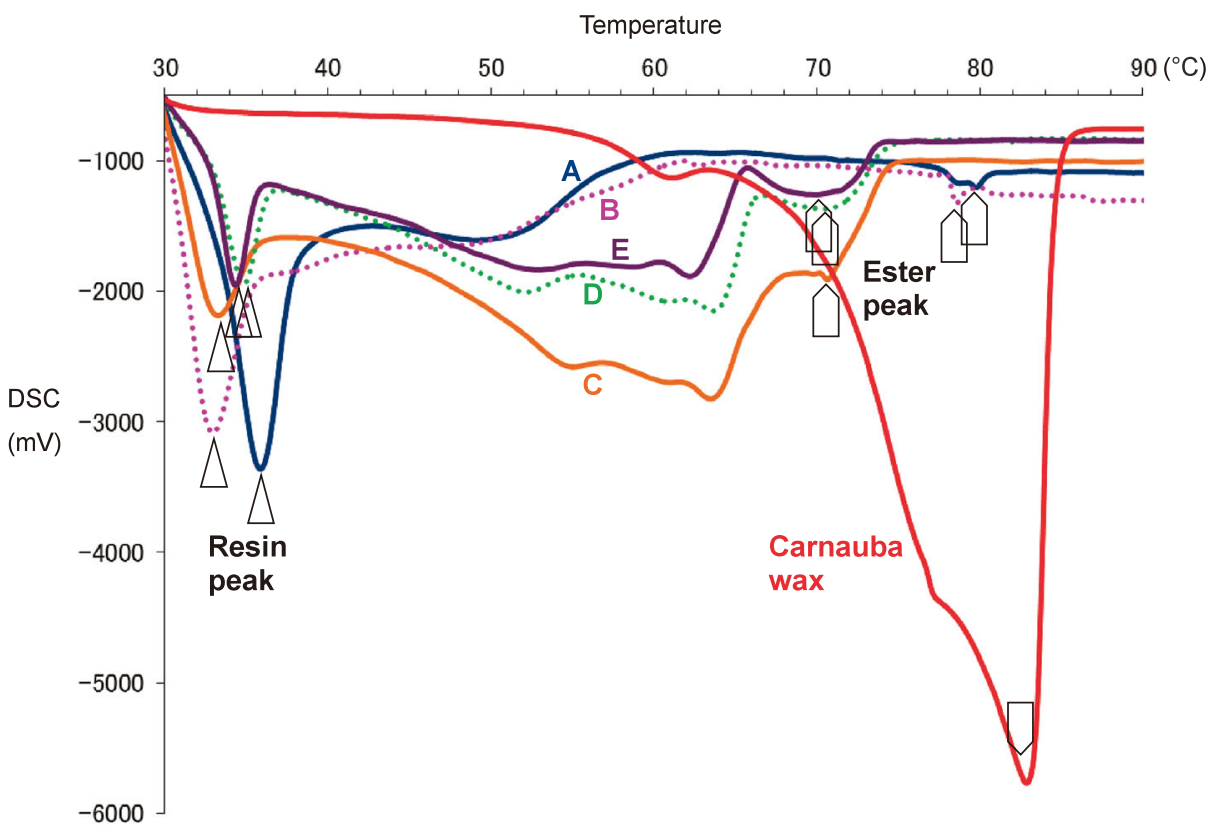

Fig. -5 DSC chart (heating-up process, heating-up speed is set to $5^{\circ} \mathrm{C} / \mathrm{min}$ ) for extraction samples. 
Table-4 The ratio of resin / ester of extraction samples estimated by DSC chart.

\begin{tabular}{lcccccc}
\hline Sample No. & A & B & C & D & E & $\begin{array}{c}\text { Carnauba } \\
\text { wax }\end{array}$ \\
\hline $\begin{array}{c}\text { Ratio of } \\
\text { resin/ester }\end{array}$ & $\underline{21.4} / 1$ & $\underline{15.2} / 1$ & $\underline{1.34} / 1$ & $\underline{1.01 / 1}$ & $\underline{0.70} / 1$ & $\underline{0.063} / 1$ \\
\hline
\end{tabular}

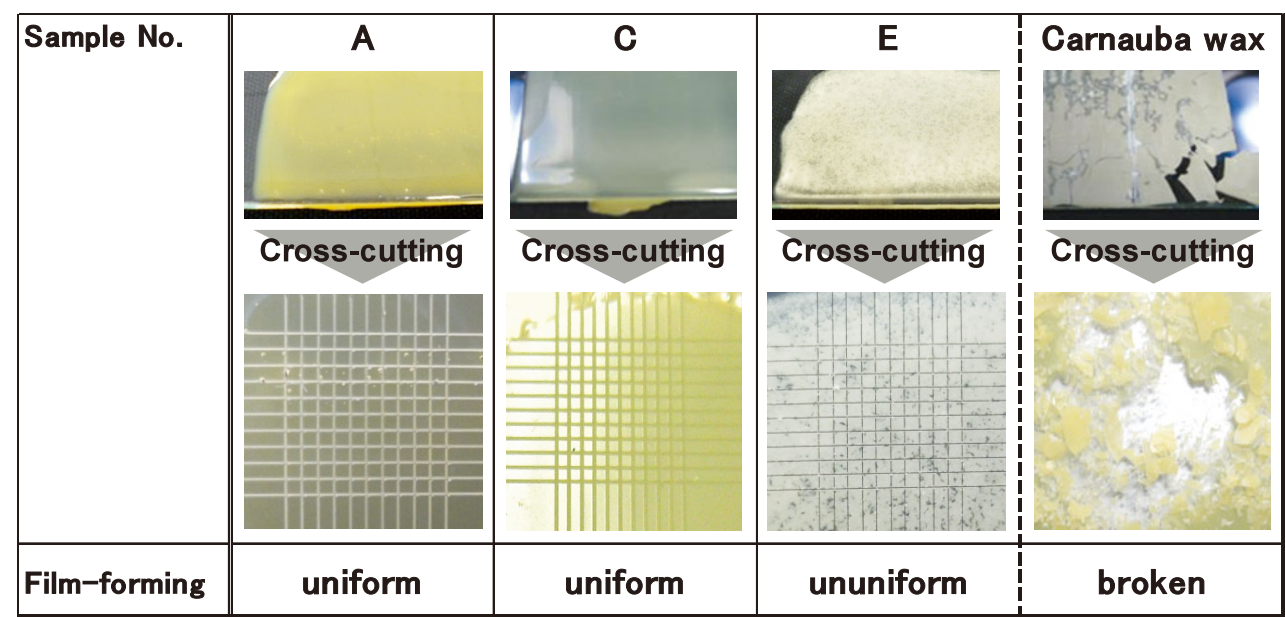

Fig.-7 The state of coating film of each sample on the glass substrate.

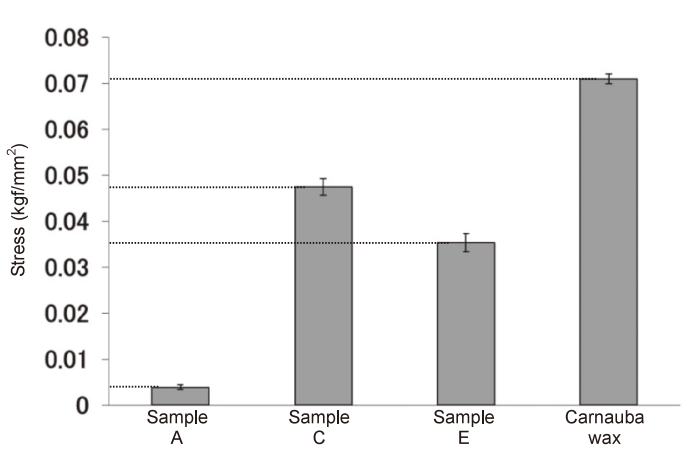

Fig.-6 The results of hardness of extraction samples, values are the mean $\pm \mathrm{S}$. D. ; $N=3$.

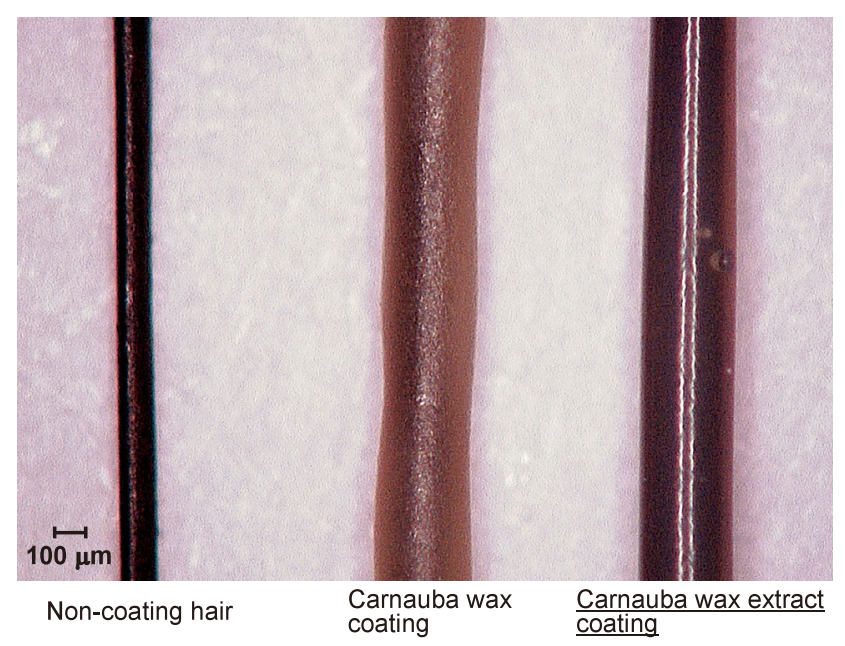

Fig.-8 Microscopic images (a magnification of 100 times) of coated hairs.

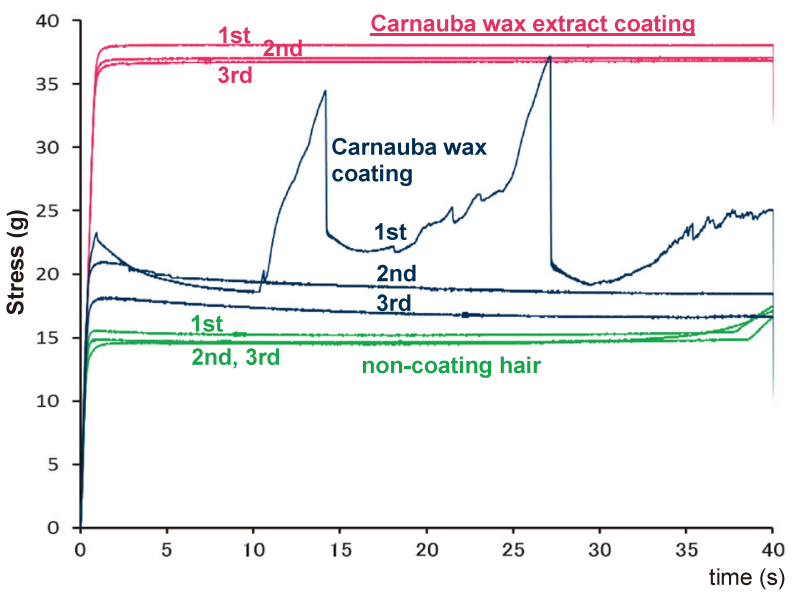

Fig. -9 Stress behavior of coated hair samples in the bending tests.

サンプル C, D, E においてはワックス成分が支配的であ ることが示唆された。

\subsection{3. 熱分析による成分組成解析}

次に，示差走査熱量計による熱分析の結果を Fig. -5 に示す。カルナウバワックスの DSC スペクトルにおい ては， $80^{\circ} \mathrm{C}$ 付近のエステルに由来するピークが非常に大 きく, レジン由来のピークは観察されなかった。一方,

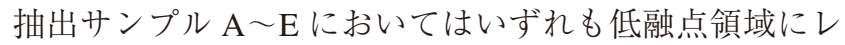
ジン成分に由来するピークが現れており，エステルに由 来するピークは減少していた。このエステルとレジンの ピーク面積を計算し，比をとることにより，各サンプル 
に含まれるレジン成分の量を推定した結果を Table-4に 示す。サンプル $\mathrm{A}$ と $\mathrm{B}$ ，そしてサンプル $\mathrm{C} \sim \mathrm{E}$ は互いに 值が近似しており, 結晶構造解析の結果を反映したもの となった。しかし，スペクトルパターンに注目すると， サンプル A と B, サンプル D と E は互いに近似してい たが, サンプル C は中融点領域のピークが大きく, ほ かのどのサンプルのスペクトルパターンとも異なるもの であった。

\section{2. 物性把握による最適サンプルの決定}

\subsection{1. サンプルの絞り込み}

3.1. での結晶構造解析および熱分析の結果により, サ ンプル A と B, そして D と E において互いの結晶構造 および成分組成が類似していることがわかったため，B と D はその後の検討の対象から除外することとした。 そして, 残りのサンプル $\mathrm{A}, \mathrm{C}$, および $\mathrm{E}$ の中から求め る物性を有するサンプルを見出すために, 硬度および柔 軟性の評価を行った。

\subsection{2. 硬度の評価}

レオメーターを用いた各サンプルの硬度の評価結果を Fig.-6に示す。レジン濃度の最も大きいサンプル A の 硬度は, 原料であるカルナウバワックスと比較して約 95\%の大幅な低下がみられた。一方で, 結晶構造解析に おいてエステル成分に由来する結晶が多数観察されたサ ンプル CおよびEについては, サンプル A ぼの大幅 な硬度低下はみられず, カルナウバワックスと比較して それぞれが約 $33 \%$ および 50\%の低下にとどまり，ワッ クス由来の硬さを有していることがわかった。

\subsection{3. 柔軟性の評価}

塗膜の柔軟性を評価するために, クロスカット試験機 で切り込みを入れる前後でのガラス板上における各サン プルの塗膜状態を観察した。その結果を Fig.-7に示 す。まず原料であるカルナウバワックスは硬さには優れ るものの柔軟性に劣るため皮膜が脆く, カッターで切り 达みを入れると膜が粉々に崩壊した。また, サンプル $\mathrm{E}$ の皮膜は切り込みは入れられたものの膜全体に白い結晶 が析出し，レジン成分とワックス成分が相溶せず不均一 な状態であった。それに対し, サンプル AおよびCは ガラス板上に均一な一枚膜を形成し, 切り込みを入れて もガラス板からはがれることなく格子パターンが均一に 刻まれた。このことより, サンプル A および C は, カ ルナウバワックスと比ベてレジン濃度が向上したことに より膜に可塑性が付与された結果, 脆さが解消され, 柔 軟性が向上したことがわかった。

\subsection{4. サンプルの決定}

われわれは以上の物性評価により，硬さと柔軟性とも
に良好な結果を示したサンプル C を求める皮膜形成剂 として最適なサンプルであると判断した。以下，このサ ンプル C を「カルナウバロウエキス」とよぶこととする。

\section{3. カルナウバロウエキスの機能性評価}

カルナウバロウエキスの物性として, 硬さと柔軟性を 併せ持つことがわかったが，実際にこのサンプルの皮膜 が毛髪に対して形状固定および保持効果を示すかどう か, つまり，マスカラに配合する皮膜形成剤として有用 かどうかを評価する必要がある。そこで，カルナウバ ワックスおよびカルナウバロウエキスをコーティングし た毛髪を用い，曲げ試験を行うことで，曲げ動作に対す るそれぞれのコーティング膜の応力挙動を観察した。サ ンプルとなるコーティング毛髪の拡大画像 (HIROX 社 製マイクロスコープKH-7700による撮影）を Fig.-8に 示す。カルナウバワックスおよびカルナウバロウエキス は毛髪上にほほ同じ厚さの膜を形成しているものの，力 ルナウバロウエキスのほうが膜の厚さが均一で, 表面の 光沢や透明性に優れていることがこの画像からも確認す ることができた。そして，これらの毛髪サンプルを用い て行った曲げ試験により得られた応力曲線を Fig.-9に 示す。未塗布の毛髪は圧縮直後に毛髪が曲がった段階で 応力が発生し, その後, 一定の応力を示した。そして, この曲げ動作を 2 回, 3 回と繰り返しても曲げの際にか かる応力の最大值にはほとんど変化がなかった。また， 比較品であるカルナウバワックスをコーティングした毛 髪は, 1 回目の曲げ動作の段階でコーティング膜が壊 れ, 応力の変動が不安定になり, 2 回目, そして 3 回目 の曲げの際には膜が完全に崩壊し，未塗布の毛髪と大差 ない応力パターンを示した。一方, カルナウバロウエキ スをコーティングした毛髪は, 1 回目の曲げの際に発生 する応力が未塗布の状態と比べて増大したことから，そ の皮膜は硬く形状固定機能に優れることがわかった。さ らに繰り返しの曲げ動作に対しても応力は高い状態を維 持していたことから, 皮膜が柔軟で曲げの動きに追従す るため反復的な衝撃を与えても壊れることがなく，形状 保持機能にも優れることが示された。

カルナウバロウエキスを配合したマスカラの使用試験 においては, Fig.-10に示すように，塗布直後における まつ毛のカール形状が, 比較品であるカルナウバワック スを配合したマスカラの場合と比べてより立ち上がった 形に固定されており，また塗布 8 時間後においても固定 されたカール形状が保持されていたことから, 繰り返し の瞬きによる衝撃を受けても皮膜が壊れにくいことが示 された。 


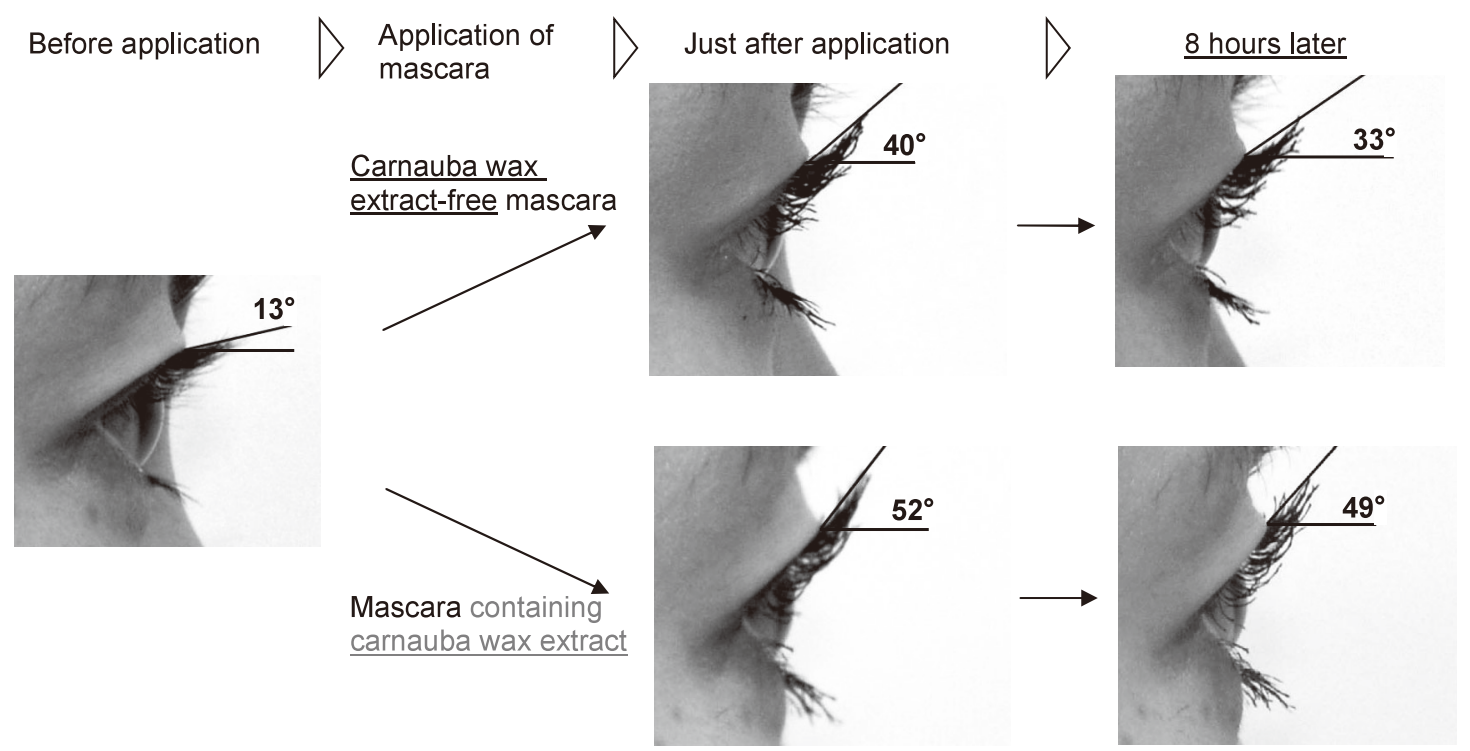

Fig. -10 Curl fixation and retention of eyelashes by the mascara containing carnauba wax extract.

\section{4. 結 論}

硬さと柔軟性を両立した「しなやか」な皮膜形成剤の 開発を目指し，カルナウバワックスを原料に，固液抽出 によりレジン成分を濃縮した新規皮膜形成剂「カルナウ バロウエキス」を開発した。カルナウバロウエキスは, カルナウバワックス由来の結晶成分に起因する硬さを持 ちながら，非晶成分であるレジン成分の濃度が大きく なっているため柔軟性にも富むという，皮膜形成剤とし て有用な性質を持つことが物性解析の結果より明らかと なった。この硬さと柔軟性を併せ持つという性質によ り，カルナウバロウエキスは毛髪にコーティングした際 に優れた形状固定および保持機能を発揮し，実際に油性 マスカラに配合することでまつ毛のカール形状の固定お よび保持機能を向上させることができた。

本研究では，マスカラにおいてカルナウバロウエキス の有用性を見出したが，カルナウバロウエキスの有する 形状保持および固定機能は「化粧持続性」が要求される 他のアイテムにおいても重要な機能となると考えられ る。今後は頭髪セット剤のような毛髪に塗布するアイテ ムをはじめ, ファンデーション, アイシャドウ, 口紅な どのメイクアイテムへの配合検討や機能評価を進め, 幅 広い製戍への展開を目指していきたい。
また，DSC 測定において，カルナウバロウエキスは 高融点のワックス成分と低融点のレジン成分以外にも中 融点成分が多く含まれていることがわかった。一般的 に，相溶させることが困難である結晶性のワックス成分 と非晶性のレジン成分を均一に共存させる上で，この中 融点成分が相溶化剤の役割を果たすことで，硬さと柔軟 性を併せ持つというカルナウバロウエキスの特徵的な物 性が実現していると考えている。今後は，この中融点成 分の詳細を解析し役割を明らかにするとともに，得られ た知見を新たな皮膜形成剤の開発に活かしていきたい。

\section{引用文献}

1）特開 2002-338436

2) 特開 2003-95874

3）三井田淳，水鳥洋一，フレグランスジャーナル，35, 59-64 (2007)

4) Y. Loginova, J. Cosmet. Sci., 60, 125-133 (2009)

5）富田由利子，フレグランスジャーナル，39, 94-95 (2011)

6）三井田淳, 奥山雅樹, 増㴊祐二, 鈴木一弘, 栗林さつ き，粧技誌，46, 197-204 (2012)

7）奥山雅樹，フレグランスジャーナル， 25, 58-64 (1997)

8）特許第 5376131 号

9）油脂抒よび油脂製品試験法部会, 油化学, 27, 336 (1978) 


\title{
Development of a Novel Flexible Film-forming Agent Derived from a Plant Wax and Its Application in Mascara*
}

\author{
Keigo Watanabe, Emi Kakizawa, Masaki Okuyama \\ Research Laboratories, KOSÉ Corporation **
}

Film-forming agents such as wax in mascara are indispensable ingredients to fix and retain the ideal eyelash shapes. Although the conventional wax films were recognized as hard and nonsticky, they were inflexible due to the high ratio of the crystalline esters. Thus, mascara films containing conventional wax easily crack and peel off as time passes due to their fragility. Therefore, mascara films with hardness and flexibility were required for any significant functional improvement of mascaras. In this study, we focused on carnauba wax which is known to be the hardest plant wax. Carnauba wax is mainly composed of wax and resin. We successfully developed a novel film-forming agent named "carnauba wax extract" by optimizing the concentration of the resin components. Physical property analyses clearly demonstrated that our carnauba wax extract film exhibited both hardness and flexibility. When applied in mascara, it greatly improved the functions to fix and retain the beautifully curled and separated eyelash shapes.

Key words : film-forming agents, mascara, eyelash, wax, resin, hardness, flexibility, carnauba wax, plant wax, carnauba wax extract 